University of Nebraska - Lincoln

DigitalCommons@University of Nebraska - Lincoln

\title{
Drivers Impacting the Adoption of Sustainable Agricultural Management Practices and Production Systems of the Northeast and Southeast United States
}

\author{
G. F. Sassenrath \\ USDA-ARS, Gretchen.Sassenrath@ars.usda.gov \\ J. M. Halloran \\ University of Maine \\ D. Archer \\ USDA-ARS \\ R. L. Raper \\ USDA-ARS \\ J. Hendrickson \\ USDA-ARS, john.hendrickson@ars.usda.gov \\ See next page for additional authors \\ Follow this and additional works at: https://digitalcommons.unl.edu/usdaarsfacpub \\ Part of the Agricultural Science Commons
}

Sassenrath, G. F.; Halloran, J. M.; Archer, D.; Raper, R. L.; Hendrickson, J.; Vadas, P.; and Hanson, J., "Drivers Impacting the Adoption of Sustainable Agricultural Management Practices and Production Systems of the Northeast and Southeast United States" (2010). Publications from USDA-ARS / UNL Faculty. 587.

https://digitalcommons.unl.edu/usdaarsfacpub/587

This Article is brought to you for free and open access by the U.S. Department of Agriculture: Agricultural Research Service, Lincoln, Nebraska at DigitalCommons@University of Nebraska - Lincoln. It has been accepted for inclusion in Publications from USDA-ARS / UNL Faculty by an authorized administrator of DigitalCommons@University of Nebraska - Lincoln. 


\section{Authors}

G. F. Sassenrath, J. M. Halloran, D. Archer, R. L. Raper, J. Hendrickson, P. Vadas, and J. Hanson 


\title{
Drivers Impacting the Adoption of Sustainable Agricultural Management Practices and Production Systems of the Northeast and Southeast United States
}

\author{
G. F. SASSENRATH ${ }^{1}$, J. M. HALLORAN ${ }^{2}$, D. ARCHER ${ }^{3}$, R. L. RAPER ${ }^{4}$, \\ J. HENDRICKSON ${ }^{3}$, P. VADAS ${ }^{5}$, and J. HANSON 3 \\ ${ }^{1}$ USDA-ARS Crop Production Systems Research Unit, Stoneville, Mississippi, USA \\ ${ }^{2}$ USDA-ARS New England Plant, Soil and Water Research Lab, University of Maine, \\ Orono, Maine, USA \\ ${ }^{3}$ USDA-ARS Northern Great Plains Research Laboratory, Mandan, North Dakota, USA \\ ${ }^{4}$ USDA-ARS Dale Bumpers Small Farms Research Center, Booneville, Arkansas, USA \\ ${ }^{5}$ USDA-ARS US Dairy Forage Research Center, Madison, Wisconsin, USA
}

Agricultural production responds to social, political, economic, environmental, and technological drivers that influence producers' decisions and shape the individual systems through modification of management practices, crop and livestock mix, and marketing strategy. We use an interview and discussion approach with producer panels to examine production systems in the eastern United States and explore key drivers impacting their unique characteristics and development. The internal social driver that values the farming lifestyle is a principle factor that leads people to choose farming. Irrespective of location, farming is first and foremost a lifestyle choice. The choice of type of production system is partly a lifestyle preference and partly influenced by other external factors, including economic and environmental elements. A second principle driver is economic, arising from a need to make a living, and tempers the internal social driver. Economic return is partially a function of the marketability of products. Marketing

This article is not subject to US copyright law.

Mention of trade names is given to provide specific information and does not constitute recommendation or endorsement by the USDA-ARS.

Address correspondence to G. F. Sassenrath, USDA-ARS Crop Production Systems Research Unit, 141 Experiment Station Rd., Stoneville, MS 38776. E-mail: Gretchen. Sassenrath@ars.usda.gov 
channels are dependent on social drivers, including education of producers and consumers, community support and community values. Farmers in the Northeast are able to take a more active role in determining contract terms than those in the Southeast, and are also more aggressive in developing new markets. Development of local markets and community support strengthens the link between farmers and consumers, and reinforces the economic sustainability of Northeastern production systems. With decreased reliance on external risk reduction approaches, Northeastern producers bear greater risk, but also have greater flexibility in altering the crop and livestock mix and are better able to respond to consumer demand.

KEYWORDS drivers, agricultural production systems, social drivers, economic drivers, risk management, entrepreneurial strategies, Maine agriculture, Alabama agriculture, commodity and specialty crops

\section{INTRODUCTION}

Agriculture is the primary mechanism for synthesis of products necessary to support life and society. As such, the health of a country's and the world's agricultural systems is critical for the continued success and support of society. However, recent economic and environmental conditions have exposed vulnerabilities in current agricultural systems. Economic fluctuations have led to rapid increases in input costs of fuel and fertilizers (NASS, 2009). The initial gains in commodity prices and net farm income following the expansion of bio-fuel production quickly evaporated due to escalating input costs. Food production will always be paramount, but in an era of diminishing or degraded resources, the importance of transitioning agricultural production towards sustainability is of increasing importance.

Sustainability has been noted to be the capacity to adapt (Holling, 2001), and is commonly recognized to have three critical elements: economic, environmental, and social (Lyson, 2002). Developing agricultural production systems that maintain adaptive capacity and address each of these elements requires careful consideration of factors influencing the successful development and implementation of production practices. The Integrated Agriculture Systems Workgroup was formed to delineate principles, criteria and indicators that underlie successful agricultural systems for physiographic regions throughout the U.S. (Hendrickson et al., 2008a). We have identified key drivers of agricultural production systems that are common to all systems, motivate specific actions within the systems, and interact to create the characteristics of current production systems (Hanson and Franzluebbers, 
2008). These key drivers were grouped into: Social-Political, Economic, Technological, and Environmental (Hendrickson et al., 2008a). Archer et al. (2008) defined internal social drivers as those factors arising from within the farm system and directing the decision-making process of the farmer. External social drivers include attitudes of consumers and societal values, and become political drivers as they are incorporated into laws such as those designed to reduce environmental impacts of production practices. Economic drivers operate both internal and external to the farm, and include government policy (price and income supports), technology, an increasingly concentrated market structure, and changing consumer demand (Halloran and Archer, 2008). Environmental drivers include natural resources (soil and water), the impact of production on the environment, and the impact of environment on production through climate, pests, or invasive species (Hendrickson et al., 2008b). Technological factors address advances in many disciplines that have been adapted for use in agriculture, including biological and engineering innovations as well as knowledge systems, such as conservation practices and computer modeling (Sassenrath et al., 2008).

In this paper, we present the results of a participatory research study with agricultural producers. The approach allows us to explore production systems and the critical issues affecting diverse operations in greater detail. We discuss drivers of production systems in the Northeast and Southeast U.S., and explore interactions between drivers and the unique characteristics of the production systems. We examine differences between the two regions and potential causes of that variation. While drivers impacting agriculture are common to both regions, the interactions between drivers and their influence on decision-makers vary substantially to create unique regional characteristics of the production systems. By examining management practices, drivers, and characteristics of the systems, we gain insight into the basis for producers' decision-making process and the underlying principles of production. We also map the transition of the agricultural production systems through the conversion process towards sustainability (Gliessman, 2010). Identification of the responsiveness of current production systems to forces that are shaping agricultural production allows us to determine successful strategies for addressing future challenges to agriculture (Hanson et al., 2008b). This information can be used by producers, scientists and policy makers to direct agricultural production and agricultural research.

\section{MATERIALS AND METHODS}

The Integrated Agriculture Systems (IAS) workgroup held workshops to examine crop and animal production practices. The workshops were held as focus groups to facilitate discussion between scientists and producers, and brought agricultural scientists from across the U.S. together with producers 
from within each region. The scientists interviewed agricultural producers to examine their production systems in detail and explore production practices, farm enterprises, and the management decision-making process. The goal is to move past the simple identification of production practices to understand the underlying rationale for their decisions, discerning the primary influences that lead to implementation of particular production practices. Information was collected at workshops held at Auburn, Alabama, November 14-16, 2005 and at Orono, ME, February 26-28, 2008.

To explore production systems consistently, we developed a series of questions for producers (Appendix A). These were developed through discussions between the organizing scientists involved in the research. The questions were used as guidelines to stimulate discussion, and not as a formal questionnaire. Questions were sent to producers prior to the on-site meeting to help them prepare for the interviews and to give them background on the research objectives. They also had copies of the questionnaire in hand during the meetings.

We identified potential interviewees by first determining the types of agricultural systems present in each area. We wanted to examine a range of system in each area including systems that accounted for the majority of agricultural sales within the area as well as niche and emerging systems. New enterprises, such as grass-fed beef, are making inroads into Northeast agriculture, though they contribute only a small percent of total agricultural products sold within the area. We first identified key production systems we wanted to examine, and then chose farmers to interview, making an effort to select producers from a range of production systems. Producers were identified by local scientists, extension personnel and grower groups to serve as panelists at the workshops.

We chose farmers who rely on farming as their primary source of income. Producers were queried as to their availability and willingness to submit to a close examination of their production systems, practices, and management choices, as well as finances and financial decisions. The panelists were farmers who regularly work closely with scientists and extension. None of the farmers considered their operations corporate farms, though several of the farms were incorporated as a legal business structure. The farms were all operated by a single, often multi-generational family. Following the interviews, the farmers were also invited to participate in discussions throughout the workshops along with the researchers. The Alabama workshop included 28 scientists and 5 producers, and the Maine workshop included 14 scientists and 8 producers. While the workshop participants differed between the two sites, a core group of 5 scientists was present at both workshops.

The meetings were arranged through the local scientists and held at the local research facilities. Producers were reimbursed for travel expenses only. Producer panels were organized around a particular production system and 
included from 1 to 3 producers. All workshop participants were involved in the interviews. The interviews were informal, and lasted approximately 2 hours. During the first hour, producers gave an overview of their production systems. The second hour consisted of scientists asking questions of the producers or discussing points for clarification to further explore the questions developed in the questionnaire. This focus group process was selected as an alternative to a formal survey or a broader set of interviews because the process enabled us to more thoroughly examine the systems and brainstorm ideas with other scientists and producers. The participatory research approach provided more interaction with the producers, a much more detailed picture of their individual operations, and enabled a richer understanding of the critical issues affecting these diverse operations. This is similar to the approach used by Hanson et al. (2004) in identifying risk management needs among organic producers. The process can be replicated by researchers at other locations (Peterson et al., 2007). The limitations of this approach are that this relatively small group of farmers may not be representative, thus conclusions drawn from this research may not reflect agriculture as a whole. To more accurately explore U.S. agriculture, we are conducting workshops at multiple locations, and taking care in selecting farmers from a range of production systems. Moreover, results of the focus group approach may be used in developing a survey instrument in order to draw broader conclusions (Peterson and Kastens, 2006).

The entire interview process was recorded on audio tape. To reduce potential loss of audio recording, later meetings were also video recorded. The audio and video recordings were transferred to $\mathrm{CD}$, and sent to any interested participants. The recordings were transcribed, with notes incorporated from scientists present. Immediately following the interviews with producers, the scientists met in small groups to discuss the information and begin preliminary development of principles, drivers, and indicators of the production systems. The producers were invited to participate in these discussions, but because of time constraints most did not. Additional questions that arose were forwarded to the producers after the meetings. Notes of the discussions were taken and compiled into a synthesis of ideas discussed. Following the meetings, the core team of scientists met over lengthy conference calls and internet meetings to rank, sort and compile the notes and transcripts. The transcripts were organized into drivers as identified in the initial meeting in Mandan, ND. At this meeting, scientists from multiple disciplines met to discuss development of principles of agricultural systems. The group identified key drivers of production, and grouped these drivers into four primary areas: social/political, economic, environmental, and technological. These primary areas serve as an organizational framework for future discussions of drivers and principles, and are used here as well.

To facilitate communication between groups of scientists from multiple disciplines and several locations, the IAS work group relies on conference 
calls and internet conferencing. We also support an online virtual office for storing results of workshops, conferences, and net meetings. The Integrated Agriculture Systems workgroup has routine conference calls to summarize results and develop work on various aspects of the research. The results presented here are a compilation of the producer panels, scientific discussions, and net conference and conference calls between IAS workgroup participants.

\section{Production Systems}

The systems examined in Orono, ME included traditional potato production, livestock production, and organic vegetable production. The livestock production systems were grass-fed beef and organic dairy. The potato producers had the largest scale of production (>200 acres), and sold primarily through contracts to commercial processors. Some individual sales to grocery chains and individuals were used to supplement income. The potato production systems had the fewest enterprises, and hence were the least diverse. Most of the acreage was concentrated in potato production with some going to small grains and corn, primarily for use as rotation crops to reduce pest pressure in the potato production. One potato producer had diversified into specialty crops, including blue potatoes and beets. The livestock producers were mid-sized, with an intermediate degree of diversity. The grass fed beef producer sold to high-end restaurants and directly to households. In addition, he brokered other items produced by neighboring farmers, expanding marketing opportunities for himself and other producers by increasing awareness of and access to organic and locally grown products. Dairy products were sold to a processor. The organic vegetable producers had small operations ( $<50$ acres), though the greatest diversity of crops produced. Widely divergent ancillary enterprises, including maple syrup production, snow plowing, and wood chopping, were included for economic benefits. The vegetable producers sold primarily to individuals, often through Community Supported Agriculture cooperatives (CSAs ${ }^{1}$ ), with some direct sales to grocery chains and restaurants.

The production systems examined in Auburn included traditional row crops (cotton, corn, soybeans, and peanuts), cattle, confinement poultry, catfish, hay, and grass-seed production. The largest scale production was the traditional row crop, which was also the least diversified. The animal systems were more diversified, primarily because of a need to handle manure, and included both crops and livestock. Catfish production was

1 In Community Supported Agriculture, producers sell subscriptions or shares to consumers, who receive produce throughout the year. The type of products available varies throughout the growing season. 
more vertically diversified, as the producer was involved in feed production enterprises. Some catfish producers are also involved in catfish processing, further diversifying the production system. The most diversified production system was farmed by the youngest grower, and included multiple ancillary enterprises. His strategy was to make every piece of land pay, so multiple enterprises were used to optimize output from the available land. Most products were sold through bulk commodity markets. Direct sales to consumers were primarily sales of commodities, such as hay, for purchase by other producers.

\section{RESULTS AND DISCUSSION}

\section{Social Drivers}

Social drivers, especially internal social drivers, are one of the two most prominent drivers impacting production decisions. Repeatedly, Maine producers said they chose farming as a way of life. They saw farming as more than just a job, but a commitment to family and heritage. This internal social driver was also the major driving force for farmers in the Southeast. This sense of heritage was more apparent in the Northeast, however, as several of the farmers interviewed were involved in multi-generational farming operations. While this difference was reflected in the producer panels, it is not reflected in statewide statistics, where the frequency of multigenerational farms is very similar (Maine 19.4\%, Alabama 23.3\%; U.S. Census of Agriculture, 2002).

In Maine, active participation of multiple generations on the farm impacted management decisions and led to both benefits and challenges. The producers were mindful of using the talents of the next generation and preparing for transitioning the farming operations to younger family members. Long-held beliefs of management practices hindered adoption of new technologies as older family members resisted change. Conversely, the need to provide for a growing family fostered the exploration of alternative production options and encouraged change. This worked to provide balance and develop strategies of calculated risk. While concern for providing sufficient income opportunities for the next generation was a challenge, the added range of talents was a beneficial mechanism to reduce risk. By bringing expertise in new technologies, such as internet marketing, the younger generation expanded opportunities for the farm and diversified the farming enterprises. It also enabled each family member to specialize in those functions (such as equipment maintenance or business management) for which they had the greatest aptitude.

Northeast producers showed a much stronger commitment to the local community and state than those in the Southeast. In addition, because Maine producers grew mostly specialty crops that were produced and sold closer to 
home, the producers' support came from the local community. This created a nexus of relationships and support. This strong community identity may arise from the long-standing support for community agriculture in the region, and hence was both an internal and an external social driver. This social driver of regional identity in turn impacted economics through marketing choices, as community support provided additional local niche markets for the sale of products. Conversely, Southeast farmers sold commodity crops mostly to long-distance buyers geographically removed from the site of production, and coincidently enjoyed little local support or marketing options.

A strong commitment to independence and less reliance on commodity supports was evident among the Maine producers irrespective of production system. Producers consistently described their desire and ability to be "price setters" instead of "price takers" (panelists' comment). Though not strictly price setters, the Maine farmers were keenly aware of the difference between selling products through bulk commodity markets in which they had no influence on price, and selling their products through marketing channels in which they negotiated price directly with the processor or consumer. This was a strikingly different philosophical approach to marketing and production options from that in the Southeast. Cotton has historically been the primary crop in Alabama. Although challenges in pest control and opportunities in other crops has reduced the overall cotton acreage and diversified production, Alabama farmers are still primarily tied to commodity crops (U.S. Census of Agriculture, 2007). While the farmers interviewed in the Southeast were frustrated by their lack of input on pricing structure, they were not as involved in the development of new markets as were the Northeast producers.

This attitude towards large scale production was applied to the development of catfish production in the Southeast (Hanson, 2002). Catfish production was initially beneficial because it allowed growers an additional crop for marginal lands, diversified production, and developed a market for other crops (catfish feed is soy based). Many of the feed and processing plants are farmer-owned cooperatives. The catfish producer interviewed was a partial owner in a catfish feed plant as well as pond production. He pointed out that, depending on the year, different portions of the catfish production stream would turn a profit. However, catfish producers do not realize benefits from local support and local markets, in part because they are marketing their product throughout the U.S. (Halloran et al., 2010). The lack of local community support significantly restricts marketing options, and is contributing in part to the current loss of market share due to pressure from imported fish (Quagrainie and Engle, 2002a; Bennett, 2008).

All producers showed a strong commitment to improving the environment, and awareness of the impacts of their production choices on the environment, both locally and globally. Not surprisingly, this was especially true for the organic producers in the Northeast. While the original choice 
of organic production was made for primarily philosophical reasons, over time that commitment shifted into making a living with organic farming. Several factors may contribute to this enhanced awareness of the interaction between production practices and the environment. These include a more tangible ability of the environment to limit production options in Maine and regional differences in the awareness of and commitment to environmental issues. Additionally, conservation programs have expanded since the first producers workshop was held in 2005. Changes in production practices in Alabama since the 2005 meeting have shown an increased environmental awareness, with more crops being rotated for maximum environmental and production benefits. Additionally, intensive research and extension programs in Alabama have resulted in a majority of row crop acreage now being farmed with conservation technologies.

The amount of certified organic land in Maine is greater than in Alabama (ERS, 2009). This most likely can be attributed to a specific social phenomenon that took place in Maine during the 1970s. At this time many 'counter culturists,' also called the "back to the landers," moved to Maine to 'return to the land' and set up farmsteads. These people were motivated by the writings of Helen and Scott Nearing as well as other environmentalists (Nearing, 1990). The movement was based primarily on organic production principles. Growth was facilitated by the presence of farms abandoned during the dairy industry contraction. Many of these people were instrumental in establishing the Maine Organic Farmers and Gardeners Association (MOFGA), the oldest and largest organic association in the United States. The development of this organization increased public awareness of and support for local agriculture, both organic and conventional. The organic producers interviewed all cited strong philosophical commitments to organic production as a key factor influencing their production choices. Not only were these growers active in production associations, they also were involved in developing community support and awareness through outreach and information exchange. Interestingly, while the Northeast has a strong regional identity (typical production promotions were "Grown in Maine for Mainers by Mainers" (panelists' comment)), input and acceptance of new ideas came largely from people who had moved to Maine from other areas.

Another difference between the Northeast and Southeast producers was the aggressive approach to acquiring information in the Northeast. While producers from both regions were considered innovators and cultivated close ties with university, extension, and federal scientists for assistance with production problems, Maine producers took a much more active role and broader approach to getting the information they needed. This was partially due to an absence of reliance on program crops, as well as a lack of information on production and management of alternative crops from traditional sources. Rather than trying to make traditional row crop production profitable, their attitude concentrated more on making a living at 
farming, and included forays into completely untried crops, products, and markets in an effort to discover what could be made or grown, how to grow it, and how to sell it. These included blue potatoes, candy striped beets, and on-farm bio-fuel synthesis. The Maine producers also saw interaction with other producers as a critical component in expanding their production and marketing knowledge. Even such diverse production systems as pineapple production were seen as useful for offering insights into alternative enterprise management options (panelist's comment). This exchange of information was encouraged individually and through participation on producer boards. Maine producers were willing to take risks into unproven areas, and dropped those enterprises or practices that were not economically viable.

In contrast to Southeast producers, Maine farmers did not have major complaints of labor shortages. They recognized that competition from other industries reduced their potential labor pool, but for the most part were satisfied with the available labor. This may be in part because of reduced overall labor needs and greater reliance on family members for on-farm labor. Also, producers in the Northeast hired laborers at a rate significantly above minimum wage, which is greater than the reduced wage allowed agricultural employers; this may have enabled them to hire more skilled laborers.

Social issues and opinions become evident through implementation of policies and regulations. Producers in both regions were politically active, but their issues and concerns varied. Alabama producers were most concerned about farm policy, especially continuation of price and income supports and conservation title mandates. Maine potato producers were less concerned about government policy. Their political efforts were directed towards improving research funding, market expansion, and trade issues. All potato producers interviewed had served on the Maine Potato Board and the National Potato Council. The organic producers interviewed were represented by and active in MOFGA.

The strong environmental commitment in Maine translated into policy through the ban on use of genetically altered varieties until just recently (Mack, 2007). The organic growers saw this ban on GMOs as critical to the health of the population and their production systems. The potato farmers saw the recent reversal of the ban on GMO crops and approval of the use of GMO corn as a benefit for insect control.

As in the Southeast, the farms observed in the Northeast were much more diversified than the national average (Dimitri et al., 2005). Farm policy had little to do with the level of diversification. Rather, expansion of markets, control of pests, and answering to consumer interests led to diversification of production. Producers in both regions saw diversification of crops and enterprises as a necessary component of creating a fiscally solvent production system. 


\section{ECONOMIC DRIVERS}

Economic drivers are also one of the most prominent drivers on which producers base their decisions. For producers, economic concerns include having the capital to initiate production, managing risk, marketing the output, and net return. Producers in both regions and across all production systems stressed the need to provide a decent living for their families. However, the degree of importance of each of the other economic factors varied between the regions.

The crop and livestock mix that the producer uses to make a living are somewhat dictated by environment, but also greatly influenced by the internal social values of the individual, as discussed above. The adoption of a particular production system also determines and depends on available marketing channels. In general, shifts in cropping systems and trends in loss of crop acres and number of farms have been similar in both states from 1959 to the present (U.S. Census of Agriculture, multiple years), reflecting the nationwide loss of farmland (Dimitri et al., 2005). With respect to livestock production, both states showed large decreases in numbers of milk cows. Other livestock inventories were reduced, with the notable exception of poultry in the Southeast.

Interviewed producers from both states recognized the need to diversify production to reduce risk. All production systems examined were diversified in crops, livestock, and other enterprises (woodlots, maple syrup production, etc.). Maine organic vegetable producers were adamant that crop diversity was a key to reducing risk, and produced as many as 50 different crops. If one crop failed, others were likely to succeed, providing consistent products to market. This strategy was complemented by planting vegetables with different growing seasons and storage characteristics so they could have products to sell about ten months each year. The potato system was the least diversified. Traditionally, a 2-year rotation of small grain rotated with potato was used. However, in areas where livestock and potato production were in close proximity, producers often exchanged fields. For instance, a potato farmer would plant alfalfa (or corn or other forage) on his land, use the cow manure and allow the dairy to harvest the forage. In turn, the dairy producer would 'lend' some land for potato production. The following year, this field was largely weed free and well cultivated, reducing costs for the dairy to plant forage. While the individual farm may not be diversified, this neighborly exchange of fields allowed greater regional diversity of production. Without close social ties however, this type of arrangement is less likely to have been implemented (Hoshide et al., 2004).

While cropping patterns and changes in farm numbers and size vary little between the two states, production practices and approaches to risk management are substantially different (U.S. Census of Agriculture). Alabama's production of program crops (crops eligible to receive price 
and income supports through the government policies) dwarfs that in Maine, where systems favor specialty crops (fruits and vegetables, tree nuts, dried fruits, and nursery crops; Martin, 2008). These state-wide trends were reflected in the producer panels. Production and marketing decisions of the farmers interviewed in Maine were primarily geared toward livestock and potatoes, with much less dependence on commodity program crops. Commodity crops (primarily grain and silage corn) were only a small portion of total production, and were grown more as a rotation to reduce pests in the potato system. Statewide, $17 \%$ of Maine farmers received subsidy payments of some form, accounting for $4 \%$ of total cash payments to producers (U.S. Census of Agriculture). In contrast, 28\% of Alabama farms received subsidy payments representing $42 \%$ of total cash payments (U.S. Agricultural Census). These statewide differences in percent commodity crop production were reflected in the attitudes of the producers interviewed, and impacted how the producers viewed their relationship with the marketing systems and the degree of flexibility they had to change their production systems.

In Alabama, some non-program crops were incorporated into the production system, though program crops clearly dominated. While reliance on program crops provided Alabama farmers a safety net, it also reduced the system flexibility. Moreover, the Southeast farmers interviewed felt they were often "farming the subsidies" (panelists' comment). They were not happy with the situation, but felt they had few viable options to remain economically solvent (Sassenrath et al., 2009). Moreover, investments in specialized and expensive equipment associated with commodity crop production further limited their ability to explore alternative crops and marketing options (Martin and Cooke, 2002).

Alabama producers were more likely to insure their crops, as approximately $11 \%$ of the cropland statewide was insured versus only $5 \%$ in Maine, which again most likely reflects the crop mix (U.S. Agricultural Census). Specialty crop producers find it more difficult to insure their crops due to the wide variety of crops and the increased actuarial risk facing insurers. Thus, in Maine, the primary purchasers of crop insurance were limited to potato and small grain producers.

The majority of America's farmers have no inherent market power to influence the prices they receive for their output, and are limited to selling at the price set by the buyers. In contrast, Maine producers had a greater ability to influence the price received than their counterparts in Alabama, making them "price setters." The ability to negotiate prices resulted in part from direct marketing to consumers through CSAs, farmers' markets, and direct sales to local stores and restaurants. Support for the small niche markets also came from growers' groups. For example, the organic milk producer sold to an organic milk processor and had negotiated the price for the year through the Maine Organic Milk Producers (MOMP). The larger producers were also very aggressive in developing their own markets, giving them 
greater flexibility in contracting and sales. As one producer stated "we try to make our farm (products) irreplaceable to our customers."

In contrast, Alabama producers had little leverage to set price with their buyers, largely because most sales were commodity sales on global markets. The major enterprises represented in the Alabama producer panels were cotton, corn, contracted poultry production, and pond-raised catfish production. Marketing associations formed to increase overall prices for these commodities have had mixed results. For example, the catfish producers had some success in coordinating their production to match temporal swings in market demand, thus avoiding seasonal low prices. However, even with better coordination, annual average prices have not increased due to pressure from imports and a lack of willingness of U.S. buyers to pay the additional expense of U.S. produced fish (Quagrainie and Engle, 2002b).

Forward contracting of production was used in both regions to manage risk, though with strikingly different results (Halloran et al., 2009). The Maine potato producers viewed their contracts as highly favorable. The potato marketing contracts did not specify production practices with the exception of variety. The contracts were negotiated on an annual basis, and most potato producers were represented by Maine's Agricultural Bargaining Council. This enabled potato producers to provide a unified stance when negotiating with the processor.

In Alabama, the poultry producers were very discouraged with the contracting process (Sassenrath et al., 2009). They viewed their contracts as millstones around their necks and likened their situation to indentured servants. The producers were frustrated that they had little influence over the production process. Due to the long-term nature of the contract and capital required for start-up and improvements, the producers couldn't afford to get out. Since the producers negotiated on an individual basis, they were in an extremely weak position. Although there have been some attempts to form bargaining associations (Archer et al., 2008), Alabama lacks laws regarding their formation and unions are not well supported in the state.

In the absence of commodity price supports, farmers could reduce marketing risk and ensure adequate prices for products through marketing contracts. Contract sales were potentially more flexible than commodity payments, allowing producers to adapt to changing market conditions. Contracts were direct negotiations between the producer and the purchaser, often a processor. Producers in both the Northeast and Southeast used contract sales as a risk reduction tool. However, the marketing contracts in which the Maine potato producers retained production control and bargaining power were more successful and more flexible than the production contracts of the Alabama chicken producers. The poultry production contracts restricted the production system and reduced flexibility.

The marketing success of the different production systems also depended on external social drivers through its impact on the development 
of marketing channels. Catfish production was developed in the Southeast in the 1960s as a specialty crop (Lovell, 1979). The abundant natural resource base and initially low feed costs resulted in rapid expansion of catfish production and its supporting industries. Southeast growers targeted large-scale production, with national and global markets. The catfish industry has grown rapidly over the past 40 years, creating a successful production system. However, in the past 1 to 2 years, catfish production has been decimated (Bennett, 2008). Exceptionally high soybean prices have increased the cost of producing catfish feed, and also made the production of soybeans more profitable than catfish, resulting in the conversion of catfish ponds to row crop production. Although catfish producers lobbied extensively for countryof-origin labeling, the importation of cheaper alternatives (tra and basa) from overseas has out-competed the U.S.-grown catfish market (Bennett, 2008). Although producers thought they were entering a differentiated market, they were still entering a global economy. By trading U.S.-grown catfish on the global market, producers opened up the product for importation of cheaper fish produced in competing nations.

In contrast, the production efforts of organic vegetable and grass-fed beef producers in Maine were specifically devoted to meeting local demand. Most producers marketed their products through farmers' markets or community supported agriculture, though some producers also sold to high-end restaurants and supermarkets, many of which were regional in scope. Maine residents have been strong supporters of locally produced food. Maine producers were well positioned to serve a growing number of consumers in the region, who place a high priority on buying locally. In contrast, catfish growers do not have the same level of regional support that local farmers have in Maine. In Maine, the organic and alternative market sectors (such as CSAs and grass-fed beef) are the fastest growing segment of agricultural production (ERS, 2009). These markets are almost non-existent in Alabama. This freedom of farming options, regional identity and support for agriculture result in a broader view of and support for alternative production agriculture.

\section{ENVIRONMENT}

The interaction between soils, landscape, and climate determine the kinds of crops and livestock that can be produced in an area, and optimal management strategies (Padbury et al., 2002). The environment is an external factor that resulted in significant differences between the production systems and practices in the Southeast and Northeast. The producers from Maine reported that the harsher environment in Maine created more challenges to production. The cold temperatures and short growing season limited crop and animal production. Alternative measures, such as hoop houses and barns, 
were required to extend the season. These added expense to the production system and restricted the ability of producers with limited capital to expand.

Maine soils are rocky, steep, and highly eroded as a result of historical production practices. During the 1970s, the state saw the opportunity to reclaim defunct dairy farms. These highly eroded lands with poor soils were readily available and inexpensive. Small, organic production systems were encouraged, and producers moved into the state to reclaim and reestablish production on these worn-out soils. Both traditional and organic producers interviewed emphasized the importance of rebuilding soil as a key component of improving their production systems. However, the colder climate, especially in the northern portions of Maine, limited the use of soil-building practices such as cover crops. Farmers in Alabama also saw soil as a primary factor determining their production success. In their case, the high cost of rented land and competition from other farmers for improved land restricted their use of soil-improving practices to land that they owned (Sassenrath et al., 2009; Soule et al., 2000).

Approximately one percent of Maine's cropland is under conservation programs as compared to 5\% in Alabama (U.S. Census of Agriculture). Some of the Maine producers interviewed felt slighted with respect to conservation programs since Maine's climate restricts the successful implementation of some conservation practices. Establishment of winter ground covers for green manures or improving soil organic matter is difficult due to early freezes in Maine. However, crop residues left on the soil surface in Maine may be more likely to last through the winter months due to the cooler temperatures that don't quickly degrade the organic matter. In the South, there is more potential to generate crop residue whether from cash or cover crops, but the higher temperatures and humidity quickly decompose and eliminate crop residues and organic matter. Variable success of conservation practices has been observed in other states with environmental conditions and soils outside the norm, and indicates the need for a close examination of conservation programs, payments and objectives (DeFelice et al., 2006).

Geographic distribution was also a factor in Maine agriculture, though in comparison to Alabama, the distribution of population centers was a more important factor than the distribution of fields. In Maine, the small-scale potato and organic vegetable farmers used their proximity to population centers to increase their marketing options. The regional identity and strong support of community agriculture created niche markets for these producers and increased sales. For the larger producers, geographic distribution was also important, though they had a greater sales area. For the biggest producers, their proximity to larger population centers along the eastern seaboard allowed them to out-compete other states for sale of their products. This was becoming especially important as transportation costs increased with rising fuel prices. As in the Southeast, the close proximity of neighboring 
farms enhanced collaborations, such as the exchange of manure and forage between cow and potato producers.

As in any production setting, pests were major concerns in Maine that required control to improve production and limit damage. The presence of pests such as Colorado potato beetle, late blight and other soil borne diseases in potatoes led to diversification of the system through use of small grain rotations to reduce infestation. Organic vegetable producers used a wide array of natural methods and crop rotations to manage pests, though were often frustrated by the short season and colder temperatures that limited residue management. Beef and dairy producers used alternative forages to limit pest infestations, though they often needed to resort to chemical controls.

\section{TECHNOLOGY}

In keeping with the entrepreneurial spirit and aggressive approach to learning, the producers in the Northeast were willing to try new technologies, even if unproven, provided the technology fit with their production philosophy. Not surprisingly then, the organic growers were staunch opponents of genetically modified organisms, while the traditional farmers saw benefits from genetically engineered crops.

An interesting component of education is that producers learned from sources that they valued. While producers interviewed from both regions were avid learners and had post-secondary education, the sources for their information varied depending on the production choices. Traditional producers gathered information from university, extension, and federal scientists. They used the internet to expand their knowledge base beyond that which was available locally. This knowledge base was further expanded by younger family members coming into the business. The organic producers went to non-traditional sources for their information, tending to rely on information from organic and progressive sources including those outside of production agriculture. All organic producers referenced background readings from authors such as Rachel Carson and Paul Sears as being key influential figures in their choice of organic production systems. This may arise at least in part from a lack of educational resources on organic production from traditional sources. To be willing to accept information from a source, farmers need to see their same internal social values in the educator. This is an important consideration when determining how best to transfer technology, especially new knowledge and production practices, to the agricultural community (Sassenrath et al., 2008), and will play a key role in transitioning agriculture to sustainability (Gliessman, 2010).

The traditional, large scale producers from both regions were more mechanized than the smaller producers. This may result both from access 
to capital and the scale of their production systems. Implementation of new technologies, especially those requiring large capital investments, was often limited due to lack of funds. The producers, especially the larger, more traditional producers, saw implementation of new technology as a means of reducing input costs, e.g., allowing them to move to once-over field preparation or harvest operations.

All of the producers interviewed used computers, especially for marketing decisions and knowledge acquisition. Producers used the internet for following price trends and markets, as well as establishing marketing outlets. The producers also used the internet to gather information on potential crops and crop production practices. Acceptance and use of computer technologies was somewhat age-related, as has been observed in other studies (Batte, 2005). While acceptance of computer technologies was wide-spread, none of the producers were using decision management tools or information systems such as crop models to make production decisions. These technologies may have only limited applicability to the production systems and setting of this study.

\section{CONCLUSIONS}

The U.S. agricultural production system has undergone rapid and significant changes in the preceding century (Hendrickson et al., 2008c). The continued success of agriculture will depend on its ability to address future challenges in natural resource degradation, increased competition for land and water resources, and changing market demands (Hanson et al., 2008). The willingness of farmers to try new crops, management practices, and production systems will determine the future responsiveness, adaptability and long-term success of agricultural production. Transitioning agriculture to sustainability will require moving beyond the current agricultural paradigm, and incorporating societal goals (Gliessman, 2010).

The panel discussions in Alabama and Maine highlight the primary drivers and how they impact the decision-making process and implementation of particular management practices and choice of agricultural systems. These drivers are a mechanism through which producers, scientists, and policymakers can maneuver agricultural systems towards more sustainable choices. In examining the production systems, we also see the progression of conversion towards more sustainable systems (Gliessman, 2010). The least sustainable system, confinement poultry, is highly constrained due to the production contracts, disallowing any integration with other enterprises that would reduce external inputs. Alternatively, young, entrepreneurial producers with a strong commitment to sustainable production are establishing close ties with consumers and developing markets and social support for new products. 
In both states, the internal social driver led to the choice of farming as a lifestyle. A strong sense of heritage, ties to the family and the desire to pass the farm on to future generations affected farmers' values and ultimate decisions. Knowledge influenced the farmers' values, resulting in changes in production practices towards those consistent with the farmers' values.

The success of the farming operation was predicated on the economic return on investment, which was partially a function of the marketability of products. Marketing channels were dependent on social drivers, including education of producers as well as consumers, community support and community values. This is similar to the entrepreneurial social infrastructure needed to foster community development (Flora and Flora, 1993). Successful development of new marketing channels in the Northeast arose from development of networks linking producers, processors and consumers, and is a critical component in moving agriculture towards sustainability (Gliessman, 2010). These networks were important for incorporating new practices in production systems and expanding marketing opportunities through increased community awareness and support. Rather than trying to make traditional systems work, Maine farmers were more aggressive in identifying marketing opportunities and creating new markets. Taking an active role in creating and expanding marketing channels gave the Maine producers greater flexibility in responding to consumer demands.

The local marketing channels in the Northeast contrasted with the global marketing channels predominant in the Southeast. Commodity crop programs were a major marketing channel used by producers in Alabama to ensure profitability and reduce marketing risks. Greater reliance on program crops limited the flexibility of producers to significantly alter their cropping mix and respond dynamically to changing consumer interests. It also limited the ability of producers to negotiate price, and hence restricted producers' control of their economic return. The development of catfish production and markets along similar lines of large-scale production and global sales exposed the product to global competition, and limited regional and national support. Although pond-raised fish production is nearly an ideal sustainable crop for protein production (Lovell, 1979), delivering highly nutritious protein at a high rate of feed conversion with a positive environmental impact, the current marketing strategy has failed as consumers opt for cheaper imported fish of questionable production background (Bennett, 2008). This also demonstrates the importance for consumers and agriculturalists with visions of and commitment to sustainability to support more sustainable production enterprises (Gliessman, 2010).

Continued success of agricultural production requires flexibility of the production systems to respond to changes in markets and consumer demands. While shifting risk is an appropriate strategy to improve return, it can limit flexibility by tying producers to a particular market. Several factors can reduce the flexibility of production: too great a reliance on market risk 
reduction techniques, loss of control or input into production and marketing, excessive commitment of financial resources for supporting infrastructure (e.g., production and processing equipment) and global competition. This inflexibility of production limits the transition of agriculture to move beyond the conventional approaches to improving production (Gliessman, 2010). Conversely, other factors enhance the flexibility of the production systems, contributing to its transition to sustainable production, notably: aggressive marketing strategies, collectively bargained contracts that give farmers control in the production and marketing, willingness to try new and untested crops and products, and education and access to information and experts. Producers also enhanced their economic return and flexibility by retaining a portion of their production for sales on the open market.

Sustainable agriculture will not be possible solely through the development of sustainable production, but will depend also on sustainable consumption. Enhancing the link between consumption and production is critical to a sustainable agriculture system. Community support and knowledge of farming systems and the contribution of farming to the local economy and environment were key aspects of the success of Maine producers. It will be interesting to observe if the current success of the regional specialty crop and livestock markets of Maine continues through the economic downturn, or if consumers choose less-expensive imports.

To transition U.S. agricultural production towards sustainability and address future challenges of resource limitations, food accessibility, nutrition and security, and changing consumer demands will require agents of change. These agents will need to be positioned at all levels within the agricultural production and consumption systems. Internal change agents will introduce new management practices and production systems within individual farms, as well as developing networks with external agents. These internal change agents will be empowered by agents who play a supporting role to production, such as educators, scientists and extension personnel, who will provide further opportunities through education, development of new methodologies, crops and value-added products, and further expand the network. External agents will link consumption to production, and complete the development of the supporting infrastructure and network. These agents will be critical in assisting in the development of new marketing channels, product acceptance, and knowledge within the consumption community.

\section{ACKNOWLEDGMENTS}

The authors are indebted to the producers who gave their time and shared their expertise with us. 


\section{REFERENCES}

Archer, D.W., J. Dawson, U.P. Kreuter, M. Hendrickson, \& J.M. Halloran. 2008. Social and political influences on agricultural systems. Renew. Food Agric. Syste. 23(4):272-284.

Batte, M.T. 2005. Changing computer use in agriculture: evidence from Ohio. Comp. Electr. Agric. 47:1-13.

Bennett, D. 2008. Catfish industry swamped by rising costs. Delta Farm Press. Available online at: http://www.deltafarmpress.com/markets/catfish-update0808/index.html (Accessed 27 Feb 2010).

DeFelice, M.S., P.R. Carter, \& S.B. Mitchell. 2006. Influence of tillage on corn and soybean yield in the United States and Canada. Online. Crop Management doi:10.1094/CM-2006-0626-01-RS.

Dimitri, C., A. Effland, \& N. Conklin. 2005. The $20^{\text {th }}$ century transformation of US agriculture and farm policy. Economic Information Bulletin EIB-3. US Department of Agriculture, Economic Research Service, Washington, D.C.

Economic Research Service. 2009. Briefing Room: Organic Agriculture. http://www.ers.usda.gov/Briefing/Organic/ (Accessed 27 Feb 2010).

Flora, C.B., \& J.L. Flora. 1993. Entrepreneurial social infrastructure: A necessary ingredient. Ann. Am. Aca. Polit. Soc. Scie. 529:48-58.

Gliessman, S.R. 2010. The framework for conversion. In: S.R. Gliessman and M. Rosemeyer. (eds.) The conversion to sustainable agriculture. CRC Press. Boca Raton, Fl. pp. 3-14.

Halloran, J.F., \& D.W. Archer. 2008. External economic drivers and integrated agricultural systems. Rene. Agric. Food Syst. 23(4):296-303.

Halloran, J.F., G.F. Sassenrath, D.W. Archer, J. Hendrickson, J. Hanson, \& P. Vadas. How drivers shape the economic sustainability of agricultural systems: Results from farmer panels. Appl. Econ. Lett. (Submitted).

Hanson, T. 2002. Marketing strategies of the catfish institute: 1985- 2001. Mississippi State University, Department of Agricultural Economics, AEC Information Report, 2002-006, November 2002.

Hanson, J., R. Dismukes, W. Chambers, C. Greene, \& A. Kremen 2004. Risk and risk management in organic agriculture: views of organic famers. Renew. Agri. Food Syst. 19:218-227.

Hanson, J.D., \& A. Franzluebbers. 2008. Principles of integrated agricultural systems. Renew. Agric. Food Syst. 23(4):263-264.

Hanson, J.D., J. Hendrickson, \& D. Archer. 2008. Challenges for maintaining sustainable agricultural systems in the United States. Renew. Agric. Food Syst. 23(4):325-334.

Hendrickson, J.R., J. Hanson, D.L. Tanaka, \& G.F. Sassenrath. 2008a. Principles of integrated agricultural systems: Introduction to processes and definition. Renew. Agric. Food Syst. 23(4):265-271.

Hendrickson, J.R., M.A. Liebig, \& G.F. Sassenrath. 2008b. Environment and integrated agricultural systems. Renew. Agric. Food Syst. 23(4):304-313.

Hendrickson, J.R., G.F. Sassenrath, D.W. Archer, J.D. Hanson, \& J.M. Halloran. 2008c. Interactions in integrated agricultural systems: The past, present and future. Renew. Agric. Food Syst. 23(4):314-324. 
Holling, C.S. 2001. Understanding the complexity of economic, ecological, and social systems. Ecosyst. 4:390-405.

Hoshide, A., T. Dalton, \& S. Smith. 2004. Representative farm budgets and performance indicators for integrated farming practices in Maine. Maine Agricultural and Forestry Experiment Station, University of Maine, Bulletin 850.

Lovell, R.T. 1979. Fish culture in the United States. Science 206(21):1368-1372.

Mack, S.K. 2007. Modified corn OK'd for Maine farmers: Crop engineered to include pesticide. Bangor Daily News July 28, 2007. http://pqasb.pqarchiver.com/ bangor/access/1311460491.html?dids $=1311460491: 1311460491 \& F M T=A B S \&$ FMTS $=$ ABS $:$ FT\&date $=J u l+28 \% 2 C+2007 \&$ author $=$ SHARON + KILEY + MACK $\%$ $3 \mathrm{BOF}+\mathrm{THE}+\mathrm{NEWS}+\mathrm{STAFF} \&$ pub $=$ Bangor + Daily + News\&edition $=\&$ startpage $=1$ $\& d e s c=$ Modified + corn $+O$ (Accessed 27 Feb 2010).

Martin, J. 2008. CSREES Anticipates Specialty Crop Research Initiative Funding Opportunity. Available online at: http://www.csrees.usda.gov/newsroom/ news/2008news/06161_speciality_crops.html (Accessed 27 Feb 2010).

Martin, S., \& Cooke, Jr. F. 2002. Mississippi Delta cotton farm structure 2002. Delta Ag. Econ, News Summer. 2002.

National Agricultural Statistical Service. 2009. 'Agricultural Prices.' Available online at: $\quad$ http://www.nass.usda.gov/QuickStats/indexbysubject.jsp?Pass_group= Economics (Accessed 27 Feb 2010).

National Agricultural Statistical Service. 2002. 'Farm computer usage and ownership.' http://www.nass.usda.gov/nh/pdf/02fmcomp.pdf (Accessed 27 Feb 2010).

Nearing, S., \& Nearing, H. 1990. The good life. New York: Schocken Books, Inc.

Padbury, G., S. Waltman, J. Caprio, G. Coen, S. Mcginn, D. Mortensen, G. Nielsen, \& R. Sinclair. 2002. Agroecosystems and Land Resources of the Northern Great Plains. Agronomy Jo. 94:251-261.

Peterson, H.H., \& T.L. Kastens. 2006. Organic grain farming in the United States: Report of the findings from a nationwide survey part I: Summary of survey responses. Presented at 2006 Risk and Profit Conference, Manhattan, KS, 17-18 August, 2006.

Peterson, H.H., T.L. Kastens, \& K.L. Ross. 2007. Risks perceived by organic grain farmers in the central USA. J. Sustain Agric. 31:5-20.

Quagrainie, K.K., \& C.R. Engle. 2002a. Implications of import and price setting policies for the catfish industry. Available online at: http://www.uaex.edu/ aqfi/research/highlights/2002/aquacultureecon/ (Accessed 27 Feb 2010).

Quagrainie, K.K., \& C.R. Engle. 2002b. Analysis of catfish pricing and market dynamics: The role of imported catfish. J. World Aquaculture Soc. 33(4):389-397.

Sassenrath, G.F., P. Heilman, E. Luschei, G.L. Bennett, G. Fitzgerald, P. Klesius, W. Tracy, J.R. Williford, \& P.V. Zimba. 2008. Technology, complexity and change in agricultural production systems. Renew. Agric. Food Syst. 23(4): 285-295.

Sassenrath, G.F., J.D. Hanson, J.R. Hendrickson, D.W. Archer, J.M. Halloran, \& J.J. Steiner. 2009. Principles of dynamic integrated agricultural systems: Lessons learned from an examination of Southeast production systems. In: P. Bohlen and G. House (eds.) Sustainable agro-ecosystem management: integrating ecology, economics and social, pp. 259-269. Taylor and Francis/CRC Press, UK. 
Soule, M. J., A. Tegene, \& K.D. Wiebe. 2000. Land tenure and the adoption of conservation practices. Am. J. Agric. Econ. 82:993-1005.

U.S. Census of Agriculture. Multiple years. Available online at: http://www.nass. usda.gov/ (Accessed 27 Feb 2010).

\section{APPENDIX A - PRODUCER QUESTIONNAIRE}

As researchers, we are examining different crop and animal production systems. Our goal is to identify principles of agricultural production that are common across different production systems, and to different geographic areas of production.

A principle is usually a rule or norm that is part of the basis for something else. For example, the ethics of someone may be seen as a set of principles that the individual obeys. These principles form the basis for their ethics.

Identifying or defining a rule as a principle says that, for the purpose at hand, the principle will not be questioned or further derived. (Wikipedia)

In this case, we are interested in determining the rules that make agriculture viable over the long term. These rules will be immutable in that they are so true to the norm that they withstand challenge from other production practices, management style, crop, geographic areas, etc. These rules, once identified, can be shared to enhance other production practices in American agriculture.

To help us discern these rules, or principles, we are asking you to share the details of your production system. We need to know the details of your operation, as well as the philosophy you used to reach the decision to implement that system. We would also like to know how external factors impact your farming operations. After you make your presentation, we will have a period of questions and discussion. We will then go into small groups to further discuss the production practices, and begin to define common rules and principles. You are welcome to participate in all aspects of the presentation and discussion.

What crops or animals do you produce?

How do you manage your production?

What factors most influence your long-range production decisions?

How does your management style serve to protect the environment?

How do you implement new technologies into your operation?

What role do genetically modified organisms play in your current operation?

Future operation?

How much time do you spend reading industry publications? 
How do you sell the products from your operation?

Who sets the price and the terms of trade for the products you produce? Do you have the ability to influence these items?

How are you affected by international trade?

Do you believe your production systems enhance your ability to manage risks, such as production or market risk?

What is the strongest aspect of your operation?

What is the weakest aspect of your operation?

How do government policies affect your operation?

How does agricultural policy, i.e. commodity supports, environmental regulations, etc. affect your decision-making?

What other agricultural enterprises are you involved in, and to what degree? What aspects of your operation will you change in the next 5 years?

How does your operation promote and sustain the local community?

What businesses will your local community gain or lose in the next 5 years?

What is your opinion concerning corporate farming?

What would you say is the most important factors that have impacted your production in the recent past?

Will these factors continue to have this impact in the future? 